\title{
Biliary Complications after Choledochocholedochostomy without T-tube in Whole-Size Liver Transplantation in Adults
}

Ousmane KA*, Olivier Boillot, Mustapha Adham, Pittau G and Gelas T

General Surgery Department, CHUA, Le Dantec, CP 3001, Dakar, Senegal, France

\begin{abstract}
Introduction: It is reported that choledochocholedochostomy without T-tube presents fewer complications than biliary reconstruction using T-tube in liver transplantation. But there is no large homogeneous series which report late and early biliary complications after choledochocholedochostomy without T-tube in whole-size liver transplantation in adults. The aim of our study was to report early and late biliary complications after choledochocholedochostomy without T-tube in whole-size liver transplantation in adults.

Materials and methods: Four hundred twenty six adult patients went whole-size liver transplantation with a biliary reconstruction performed by choledochocholedochostomy without T-tube. Forty six patients presented biliary complications. Incidence and treatment of early and late complications are studied.

Results: The overall biliary complications rate was $9.8 \%$. Early and late biliary complications rates were respectively $50 \%$. Early biliary complications were: 13 early anastomotic strictures $(28.3 \%$ of overall biliary complications); 9 early anastomotic biliary leaks (19.6\%) and 1 case of hemobilia $(2.2 \%)$. In 3 patients, early anastomotic strictures were associated with early leaks (6.5\%). There was 19 late supra anastomotic strictures developed on the graft side ( $41.3 \%$ of overall biliary complications); 3 late anastomotic biliary leaks $(6.5 \%)$ and 1 biliary obstruction by a lymphoma $(2.2 \%)$.

Conclusion: This study is a large and homogeneous series which find low rate of biliary complications in choledochocholedochostomy without T-tube in whole-size liver transplantation. There is no difference between early and late biliary complications accepted graft conservation injuries which are more frequent in late biliary complications. Strictures are more frequent than leaks in the 2 groups. Both endoscopic and surgical treatments have a good prognosis.
\end{abstract}

Keywords: Choledochocholedochostomy; T-tube; Whole-size liver transplantation

\section{Introduction}

Biliary flow re-establishment is the last step of orthotopic liver transplantation (OLT) after all vascular reconstructions. It can be performed by Hepaticojejunostomy (HJ), Choledococholedochostomy (CCS) with T-tube or choledochocholedochostomy without T-tube. This last technique is used in native bile duct disease free with suitable caliber $[1,2]$ and presents less overall biliary complications than the other procedures $[3,4]$. Since 1992, we used this technique. The purpose of this retrospective study of a large and homogeneous series is to determine the incidence, the nature and the results of treatment of early and late biliary complications in our technique of CCS without T-tube in whole-size liver transplantation in adults.

\section{Materials and Methods}

\section{Patients}

Since 1992, we performed in our institution 654 CCS in wholesize liver grafts transplantations in adults. CCS without T-tube was realized on 426 patients. Of the 426 patients with CCS without T-tube, $46(9.8 \%)$ presented biliary complications and constitutes the aim of this study. The following informations were obtained thanks to a prospective database of our hospital. The mean age of the patients (33 men and 13 women) was $49.7 \pm 9.9$ years (range $18-69$ years). The liver disease leading to transplantation was cirrhosis on 39 patients $(84.8 \%)$ and the Child score was 'A' in 9 patients (19.6\%), 'B' in 11 patients (24\%) and C in 19 patients (41.3\%). The indications of orthotopic liver transplantation are represented in table 1 . The mean age of donors was 41.4 years (range $12-72$ years). Twenty-seven recipients $(58.7 \%)$ had same sex than donors and 42 patients (91.3\%) had same blood group than donors. Four patients $(8.7 \%)$ had different blood groups than donors but were compatibles. Thirty-one recipients (67.4 patients) were infected by cytomegalovirus in pre operative period versus 27 cases of infection (58.7) in donors.

\section{Characteristics of the transplantation and technique of biliary reconstruction}

Cold ischemia mean time was 597.3 minutes, (122-970 minutes). Macro vacuolar fatty liver was observed in 18 liver grafts (39.1\%), and was upper than $30 \%$ in 8 patients (17.4\%). Injuries of graft conservation were found in 34 patients $(73.9 \%)$. The mean time of the liver transplantation was $297.4 \pm 70.7$ minutes with a 300 minutes median, (range 175-490 minutes). Warm ischemia time was 57.3 minutes (28174 minutes). Mean time of hepatic artery reperfusion was $37 \pm 14.9$ minutes. Red blood cell transfusion was effected in 40 patients $(86.9 \%)$. In these 40 patients, 21 (52.5\%) received more than 5 units of red blood cells while, at the same moment, auto transfusion was realized in 35

*Corresponding author: Dr Ousmane KA, General Surgery Department, CHUA Le Dantec, CP 3001, Dakar, Senegal, France, Tel: +(221) 776355151; E-mail ousmaneka@yahoo.fr

Received February 21, 2012; Accepted August 27, 2012; Published August 30 2012

Citation: Ousmane KA, Boillot O, Adham M, Pittau G, Gelas T (2012) Biliary Complications after Choledochocholedochostomy without T-tube in Whole-Size Liver Transplantation in Adults. J Liver 1:112. doi:10.4172/2167-0889.1000112

Copyright: (c) 2012 Ousmane KA, et al. This is an open-access article distributed under the terms of the Creative Commons Attribution License, which permits unrestricted use, distribution, and reproduction in any medium, provided the original author and source are credited. 


\begin{tabular}{|l|c|c|}
\hline Liver disease & Effective & Percent (\%) \\
\hline Cirrhosis & 39 & 84.8 \\
\hline Alcoholic cirrhosis & 19 & 41.3 \\
\hline Posthepatitis C cirrhosis & 8 & 17.4 \\
\hline Alcoholic and posthepatitis C Cirrhosis & 1 & 2.2 \\
\hline Posthepatitis B and D cirrhosis & 4 & 8.7 \\
\hline Posthepatitis B cirrhosis & 1 & 2.2 \\
\hline Primary biliary cirrhosis & 1 & 2.2 \\
\hline Hemochromatosis & 1 & 2.2 \\
\hline Cirrhosis of unknown cause & 2 & 4.4 \\
\hline Wilson disease & 1 & 2.2 \\
\hline Hepatocellular carcinoma on cirrhosis & 1 & 2.2 \\
\hline Fulminant hepatitis & 2 & 4.4 \\
\hline Rendu Osler disease & 3 & 6.5 \\
\hline Carcinoid metastasis & 1 & 2.2 \\
\hline Hepatic polycystoides & 1 & 2.2 \\
\hline
\end{tabular}

Table 1: Indications of Orthotopic Liver Transplantation.

patients (76\%). Bile production was abundant an early in 30 patients (65.2\%), moderate in 9 patients (19.6\%) and late in 7 patients (15.2\%). In 22 recipients $(47.8 \%)$, there were differences of diameters between native bile duct and the liver graft bile duct. The diameter of graft bile duct was less or equal than 3 millimeters in 10 patients (21.7\%).

After vascular reconstructions and assessment of the bile flow quality, the biliary re-establishment was realized by an end-to-end choledochocholedochostomy. After cutting bile duct ends in wellvascularized areas, the anastomosis was realized with interrupted stitches of 6.0 absorbable materials without T-tube insertion and without any tension. In case of discrepancy between recipients and donors bile duct diameters, a bile ductoplasty was done on the end of the bile duct with bigger size.

At recovery time, early or late biliary complications were suspected in patients who presented abdominal pains, jaundice or fever associated with a dysfunction of liver biochemistry in the absence of the graft rejection, viral hepatitis reactivation or vascular thrombosis at the biopsy and Doppler Ultrasonography. The diagnosis was confirmed by abdominal ultrasonography or computed Tomography completed with ERCP. Biliary anastomosis complications were classed as early and late complications. Early complications were defined as complications which appear within one month of the transplantation. All patients were followed through June 2009 or until death. For the statistical analysis, continuous variables are reported as mean \pm standard deviation or range. To compare groups of patients (early and late complications), Fischer's exact test, Pearson's Chi square Test and Student $t$ test were used. Statistical analyses were performed with Epi Info Version 3.5.1. 2008.

\section{Results}

The higher mean rate of liver enzymes (ALAT) at the first week after transplantation was $973.5 \mathrm{U}$ (range 49-7600 U). Biliary complications are diagnosed and confirmed by ERCP between 1 day and 65.3 months after the liver transplantation with a mean period of 7.7 months (median: 36 months). The overall biliary complications observed was: 32 biliary strictures (7.5\%); 12 bile leaks $(2.8 \%) ; 1$ hemobilia $(0.3 \%)$; and 1 biliary obstruction by a lymphoma $(0.3 \%)$.

Twenty-three of the 46 patients (50\%) developed early biliary anastomosis complications: 13 early anastomotic strictures $(56.5 \%$ of early biliary complications and $28.3 \%$ of overall biliary complications); 9 patients had early anastomotic biliary leaks (39.1\% of early biliary complications and $19.6 \%$ of overall biliary complications) and hemobilia occurred in one patient $(4.3 \%$ of early biliary complications and $2.2 \%$ of overall biliary complications). In 3 patients, early anastomotic strictures were associated with early leaks ( $13 \%$ of early biliary complications and $6.5 \%$ of overall biliary complications).

Late biliary complications occurred more than one month after the transplantation in 23 patients (50\%). There was 19 late supra anastomotic strictures developed on the graft side $(82.6 \%$ of late biliary complications and $41.3 \%$ of overall biliary complications); 3 late anastomotic biliary leaks (13\% of late biliary complications and $6.5 \%$ of overall biliary complications) and one biliary obstruction by a lymphoma ( $4.3 \%$ of late biliary complications and $2.2 \%$ of overall biliary complications). There were not associations between late supra anastomotic strictures and late biliary leaks. Pre operarative characteristics of recipients, intra operative profiles and post operative recovery are respectively represented in (tables 2-4). There was more graft conservation injuries in patients who presented late complications, $\mathrm{p}=0.049$ ( $\chi^{2}$ test Yates corrected). Although, there was more CMV primo infection and longer time of cold ischemia in patients who developed late biliary complications than in the other group but the difference was statistically insignificant. At reverse, in patients who presented early biliary complications, there was more fatty liver, biliary discrepancy, poor bile flow, hepatic artery thrombosis, and intra abdominal hemorrhage and CMV post operative infection; however differences were not significant.

\section{Treatment of early biliary complications}

Among the patients who presented early biliary complications, one patient went an unsuccessful selective embolization for hemobilia and had secondary surgical ablation of blood clots and a reflection of the anastomosis on a T-tube. In patients who presented early biliary strictures and leaks, endoscopic stents without dilatation were performed in 11 patients during ERCP. This endoscopic treatment was associated with radiologic drainage in cases of biloma occurring in anastomotic leaks. Endoscopic with radiologic drainage was successful in 9 patients $(81.8 \%)$. In 2 patients (18.2\%), the endoscopic treatment failure led to a Roux-en-Y Hepaticojejunostomy conversion

\begin{tabular}{|l|c|c|}
\hline & $\begin{array}{c}\text { Early biliary } \\
\text { complications }\end{array}$ & Late biliary complications \\
\hline Mean age $(\mathrm{yr})$ & $52.9(23-69)$ & $46.5(18-64)$ \\
\hline Sex(M/F) & $18 / 5$ & $15 / 8$ \\
\hline CMV infection & $14(60.9 \%)$ & $17(73.9 \%)$ \\
\hline $\begin{array}{l}\text { CHILB B or C on cirrhotic } \\
\text { patients }\end{array}$ & $15(65.2 \%)$ & $15(65.2 \%)$ \\
\hline Cold ischemia (min) & $583.9( \pm 340)$ & $610.7( \pm 172)$ \\
\hline $\begin{array}{l}\text { Graft conservation injuries } \\
\text { Fatty liver macro vesicle } \\
>30 \%\end{array}$ & $13(56.5 \%)$ & $20(86.9 \%)$ \\
\hline
\end{tabular}

Table 2: Preoperative Characteristics.

\begin{tabular}{|l|l|l|}
\hline \multicolumn{3}{|c|}{ Early biliary complications } \\
\hline Warm ischemia time & $54.9 \mathrm{~min}(28-95 \mathrm{~min})$ & $59.6 \mathrm{~min}(35-174 \mathrm{~min})$ \\
\hline Artery reperfusion duration (min) & $35.4 \mathrm{~min}(44-78 \mathrm{~min})$ & $38.8(18-90 \mathrm{~min})$ \\
\hline Bile ductoplasty & $13(56.5 \%)$ & $9(39.1 \%)$ \\
\hline $\begin{array}{l}\text { Recipient biliary duct largest than } \\
\text { donor biliary duct }\end{array}$ & $9(39.1 \%)$ & $8(34.8 \%)$ \\
\hline Red cell transfusion(U) & $5.8(1-14)$ & $6.7(2-16)$ \\
\hline Low bile flow & $6(26.1 \%)$ & $3(13 \%)$ \\
\hline Operation duration & $296.6 \mathrm{~min}(175-420)$ & $298.2 \mathrm{~min}(195-490)$ \\
\hline
\end{tabular}

Table 3: Intraoperative Characteristics. 


\begin{tabular}{|l|c|c|}
\hline & $\begin{array}{c}\text { Early biliary } \\
\text { complications }\end{array}$ & $\begin{array}{c}\text { Late biliary } \\
\text { complications }\end{array}$ \\
\hline $\begin{array}{l}\text { First week higher mean rate of } \\
\text { hepatic enzymes }\end{array}$ & $864 \cup(82-2709 \mathrm{U})$ & $1121 \cup(49-7600)$ \\
\hline Hepatic artery thrombosis & $3(13 \%)$ & $0(0 \%)$ \\
\hline Intra abdominal hemorrhage & $3(13 \%)$ & $1(4.3 \%)$ \\
\hline CMV infection & $14(60.9 \%)$ & $3(13 \%)$ \\
\hline Acute graft rejection & $11(47.8 \%)$ & $13(56.5 \%)$ \\
\hline $\begin{array}{l}\text { Decease related to biliary } \\
\text { complications }\end{array}$ & $3(13 \%)$ & $1(4.3 \%)$ \\
\hline
\end{tabular}

Table 4: Post Operative Recovery.

respectively at 3 and 8 months. Eleven patients went early surgical treatment using a pathologic anastomosis resection combined with duct-to-duct anastomosis on T-tube in 8 patients. This treatment was successful in 7 patients $(87.5 \%)$. In 2 other patients, a suture of anastomosis discrepancy was realized with a failure in 1 patient who needed endoscopic stent 19 days later. In 1 patient, Roux-en-Y Hepaticojejunostomy was immediately realized with success.

\section{Treatment of late biliary complications}

Balloon dilatation with stent was performed in 15 patients and was successful in 13 patients (86.7\%). In 2 patients (13.3\%), there was a failure of the endoscopic treatment and Roux-en-Y hepaticojejunostomy was secondary realized in the month. Surgical treatment was primarily performed in 6 patients and was successful in 5 patients (83.3\%). Rouxen-Y hepaticojejunostomy was immediately realized in 5 patients and was complicated by a stricture which required a secondary revision 6 months later. Pathologic biliary anastomosis resection combined with duct-to-duct anastomosis on T-tube was successfully performed in 1 patient.

In 2 patients, there was neither endoscopic nor surgical treatment; patients were surveyed and didn't present any liver dysfunction.

Mortality due to overall biliary complications was $8.7 \%$ (4 patients). Mortality rate related to early biliary anastomosis complications was $6.5 \%$ (3 patients who presented severe sepsis after endoscopic treatment, pathologic anastomosis resection combined with duct-to-duct anastomosis on T-tube and refection of the anastomosis on a T-tube after embolization failure for hemobilia. Mortality rate related to late biliary anastomosis complications was $2.2 \%$ (1 patient who presented acute pancreatitis with severe sepsis after failure of both endoscopic and surgical treatment). There was any case of retransplantation.

Results of endoscopic treatment and surgery for early and late biliary complications didn't present any significant difference.

\section{Discussion}

Systematic reviews and meta-analysis of OLT results concluded CCS without T-tube presents more advantages than CCS with T-tube because of less complications like bile infections, cholangitis, fistulas and peritonitis $[3,4]$. Overall biliary complications after CCS without T-tube in OLT have an incidence of 10-30\% [3-5]. However, biliary leaks and strictures are the foremost biliary complications and contribute to increase morbidity and mortality of OLT [3-5]. Many authors pointed out this problem but many studies are heterogeneous, such Verran series [2] which reports complications of biliary reconstruction without T-tubes or stents, using CCS or Roux-en-Y hepatojejunostomy or Rerknimitr series [6] which reports complications of CCS with or without T-tube placement. In the literature, the largest series which studies biliary complications after CCS without T-tube included 131 patients [3-5,7]. That's why, in our knowledge, this study represents the first and largest homogeneous series which treat about early and late biliary complications after CCS without T-tube in whole-size liver transplantation in adults with an acceptable rate of overall biliary complications of $9.8 \%$.

Early biliary complications and late biliary complications occurred with the same incidence of $50 \%$ in this study but it is observed more overall biliary strictures than overall biliary leaks. These complications are related to multiples factors including technical mishaps, preservation injuries, cytomegalovirus infections, prolonged cold ischemia time, hepatic artery patency, ischemia-reperfusion injuries and immunological injuries (chronic ductopenic rejection, $\mathrm{ABO}$ incompatibility, blood cells transfusion) which lead to ischemic-type biliary lesions [8-11]. Early leaks and early strictures are located at the anastomotic site and are more often caused by a technical mishap even rarely; early biliary leaks are due to poor vascularization of the anastomotic site [12]. The absence of intrahepatic strictures and dilatations at the period of the diagnosis leads us to conclude that early biliary complications pathogenesis is not ischemic-type in this series. On the other hand, biliary discrepancy is found in $56.5 \%$ of patients in this series and recipients biliary duct diameters are largest than biliary tract of the liver graft in $39.1 \%$ while low bile flow is observed in $26.1 \%$ of patients. It is possible that these situations are related to the early biliary leaks. With these results, hepaticojejunostomy could be better than CCS without T-tube when a large difference of calibers between recipients and whole size graft bile ducts is discovered. Others early biliary complications like hemobilia are rare. They occur in $0.03 \%$ of recipients after a liver biopsy, percutaneous transhepatic cholangiography or after rupture of a common hepatic artery pseudoaneurysm in the bile duct [13-15].

Late biliary leaks complications occurred at the anastomotic site, while all late strictures are supra anastomotic in this study. These late complications are often the consequences of poor vascularization of graft bile duct due to either an excessive dissection of the periductal tissues, a nonsufficient trimming to well-perfused biliary tissue at both sites of the anastomosis, or to a newly occurred arterial problem [12]. Whenever, late strictures must be distinguished with obstructions of the biliary duct related to recurrence of the primary disease, cholelithiasis, extrinsic compression by cyst or lymphoma in the hepatic hilum $[7,16]$ as the one case observed in this series. In this series, strictures are more frequent than leaks, probably because T-tube were not used to stent the CCS.

The preferred method used for the diagnosis is ERCP $[17,18]$. It is also increasingly indicated, more than Percutaneous technique, to treat biliary complications $[6,19]$. It is accepted that non surgical treatment (Percutaneous transhepatic or endoscopic management) represents the first step in the therapy of biliary complications because they give the diagnostic and permit dilatations or stent placement with 70-83.3\% of good results [7,19-21]. It is well-known that endoscopic biliary dilatation should include a stent placement to ovoid a low success rate for non surgical treatment of biliary strictures $[6,19]$. Unfortunately, stent placements are responsible of bleeding, pancreatitis and retroperitoneal perforation, respectively in $3 \%, 3 \%$ and $0.6 \%$. For supra non anastomotic strictures, endoscopic treatment gives bad results with only a $30-58 \%$ rate of success $[6,22,23]$.

Surgical revision of the biliary anastomosis and new biliary reconstruction are required when leaks are associated with a wide defect of the biliary anastomosis, in very long strictures and when non surgical treatments fail $[5,12]$. In these cases, primary repair is preferred in very early postoperative time when technically feasible, it means in 
Citation: Ousmane KA, Boillot O, Adham M, Pittau G, Gelas T (2012) Biliary Complications after Choledochocholedochostomy without T-tube in Whole-Size Liver Transplantation in Adults. J Liver 1:112. doi:10.4172/2167-0889.1000112

the absence of tension between the ends of bile ducts, in the absence of infected tissues and in the absence of hepatic artery thrombosis [12,24]. If primary repair is not safe, a Roux-en-Y hepaticojejunostomy with a transanastomotic catheter have to be performed. According to the classification of biliary strictures used at Hôpital Paul Brousse [25], in the type I strictures with a common duct stamp longer than $2 \mathrm{~cm}$, Roux-en-Y hepatojejunostomy can be effected without opening the left duct and without lowering the hilar plate. In type II strictures (stump shorter than $2 \mathrm{~cm}$ ) and Type III lesions (only the ceiling of the biliary confluence is intact), it is respectively necessary to open the left bile duct and to lower the hilar plate for a satisfactory anastomosis. In our opinion, type IV lesions (interruption of the biliary confluence) and type $\mathrm{V}$ lesions (associate stricture of the hepatic duct and strictures on separate right branches) are lesions which occur after severe ischemic complications of the graft and need re-transplantation. Rouxen-Y hepatojejunostomy is a safe treatment for early and late biliary complications with few complications and low mortality rate, but it can be complicated by recurrent stenosis which require a new biliary derivation respectively in $8-4 \%[7,26]$. It appears in this series that mortality rate is higher in early biliary complications.

\section{Conclusion}

Today it is accepted than choledochocholedochostomy without T-tube is a safe biliary reconstruction technique in whole-size liver transplantation in adult with well accepted rates of morbidity and mortality. This study is a large and homogeneous series which find low rate of biliary complications with no difference between early and late biliary complications accepted graft conservation injuries which are most frequent in patients who presented late complications. However, strictures are more frequent than leaks in the 2 groups and confirmed than high rates of leaks are related to the use of T-tube as reported in the literature. Both endoscopic and surgical treatments have a good prognosis in early and late biliary complications treatment even mortality is higher in early biliary complications.

\section{References}

1. Greif F, Bronsther OL, Van Thiel DH, Casavilla A, S Iwatsuki, et al. (1994) The incidence, timing, and management of biliary tract complications after orthotopic liver transplantation. Ann Surg 219: 40-45.

2. Verran DJ, Asfar SK, Ghent CN, Grant DR, Wall WJ (1997) Biliary reconstruction without $T$ tubes or stents in liver transplantation: report of 502 consecutive cases. Liver Transpl Surg 3: 365-373.

3. Sotiropoulos GC, Sgourakis G, Radtke A, Molmenti EP, Goumas K, et al. (2009) Orthotopic liver transplantation: T-tube or Not T-tube? Systematic review and meta-analysis of results. Transplantation 87: 1672-1680.

4. Scatton O, Meunier B, Cherqui D, Boillot O, Sauvanet A, et al. (2001) Randomized trial of choledochocholedochostomy with or without a $\mathrm{T}$ tube in orthotopic liver transplantation. Ann Surg 233: 432-437.

5. Wojcicki M, Milkiewicz P, Silva M. (2008) Biliary tract complications after liver transplantation: a review. Dig Surg 25: 245-257.

6. Rerknimitr R, Sherman S, Fogel EL, Kalayci C, Lumeng L, et al. (2002) Biliary tract complications after orthotopic liver transplantation with choledochocholedochostomy anastomosis: endoscopic findings and results of therapy. Gastrointest Endosc 55: 224-231.

7. Gomez R, Moreno E, Castellon C, González-Pinto I, Loinaz C, et al. (2001)
Choledochocholedochostomy conversion to hepaticojejunostomy due to biliary obstruction in liver transplantation. World J Surg 25: 1308-1312.

8. Sanchez-Urdazpal L, Gores GJ, Ward EM, Maus TP, Wahlstrom HE, et al (1992) Ischemic-type biliary complications after orthotopic liver transplantation. Hepatology 16: 49-53.

9. Park JB, Kwon CH, Choi GS, Chun JM, Jung GO, et al. (2008) Prolonged cold ischemic time is a risk factor for biliary strictures in duct-to-duct biliary reconstruction in living donor liver transplantation. Transplantation 86: 15361542.

10. Lautenschlager I, Hockerstedt K, Jalanko H, Loginov R, Salmela K, et al. (1997) Persistent cytomegalovirus in liver allografts with chronic rejection. Hepatology 25: 190-194.

11. Evans PC, Smith S, Hirschfield G, Rigopoulou E, Wreghitt TG, et al. (2001) Recipient HLA-DR3, tumour necrosis factor-[alpha] prometer allele-2 (tumor necrosis factor-2) and cytomegalovirus infection are inter-related risk factors for chronic rejection in liver grafts. J Hepatol 34: 711-715.

12. Testa G, Malago M, Broelsch CE (2001) Complications of biliary tract in liver transplantation. World J Surg 25: 1296-1299.

13. Maguire D, Rela M, Heaton ND (2002) Biliary complications after orthotopic liver transplantation. Transplant Rev 16: 220-240.

14. Croutch KL, Gordon RL, Ring EJ, Kerlan RK Jr, LaBerge JM, et al. (1996) Superselective arterial embolization in the liver transplant recipient: a safe treatment for hemobilia caused by percutaneous transhepatic biliary drainage. Liver Transpl Surg 2: 118-123.

15. Merhav H, Zajko AB, Dodd GD, Pinna A (1992) Percutaneous transhepatic embolization of an intrahepatic pseudoaneurysm following liver biopsy in a liver transplant patient. Transpl Int 6: 239-241.

16. Colina F, Castellano V, Gonzalez-Pinto I, García I, Novo O, et al. (1998) Hilar biliary cysts in hepatic transplantation. Report of three symptomatic cases and occurrence in resected liver grafts. Transplant Int 11: 110-116.

17. Gholson C, Zibari G, McDonald JC (1996) Endoscopic diagnosis and management of biliary complications following orthotopic liver transplantation. Dig Dis Sci 41: 1045-1053.

18. Sossenheimer M, Slivka A, Carr-Locke D (1996) Management of extrahepatic biliary disease after orthotopic liver transplantation: review of the literature and results of a multicenter survey. Endoscopy 28: 565-571.

19. Schwartz DA, Petersen BT, Poterucha JJ, Gostout CJ (2000) Endoscopic therapy of anastomotic bile duct strictures occurring after liver transplantation. Gastrointest Endosc 51: 169-174

20. Rossi AF, Grosso C, Zanasi G, Gambitta P, Bini M, et al. (1998) Longterm efficacy of endoscopic stenting in patients with stricture of the biliary anastomosis after orthotopic liver transplantation. Endoscopy 30: 360-366

21. Jagannath S, Kalloo AN (2002) Biliary complications after liver transplantation. Curr Treat Options Gastroenterol 5: 101-112.

22. McDonald V, Matalon TA, Patel SK, Brunner MC, Sankary H et al. (1991) Biliary strictures in hepatic transplantation. J Vasc Interv Radio 2: 533-538.

23. Sanchez-Urdazpal L, Gores GJ, Ward EM, Maus TP, Buckel EG, et al. (1993) Diagnostic features and clinical outcome of ischemic-type biliary complications after liver transplantation. Hepatology 17: 605-609.

24. Colonna JO (1996) Technical problems; biliary. In Transplantation of the liver Saunders WB Companypp $1^{\text {st }}($ Edn) 617-625.

25. Bismuth H, Majno PE (2001) Biliary strictures: classification based on the principles of surgical treatment. World J Surg 25: 1241-1244.

26. Schlitt H, Meier P, Nashan B, Oldhafer KJ, Boeker K, et al. (1999) Reconstructive surgery for ischemic-type lesions at the bile duct bifurcation after liver transplantation. Ann Surg 229: 137-145. 